\title{
Wear and friction modelling on lifeboat launch slipway panels
}

\author{
B. Thomas ${ }^{1}$, M. Hadfield ${ }^{1} \&$ S. Austen ${ }^{2}$ \\ ${ }^{1}$ Sustainable Design Research Centre, School of Design, \\ Engineering and Computing, Bournemouth University, UK \\ ${ }^{2}$ Royal National Lifeboat Institution, Poole, UK
}

\begin{abstract}
The Royal National Lifeboat Institution provides search and rescue cover along the United Kingdom and Republic of Ireland coast using a variety of lifeboats and launch techniques. In locations where there is no natural harbour it is necessary to use an inclined slipway to launch the lifeboat into the sea. Slipway stations consist of an initial section where the boat is held on rollers followed by an inclined keelway lined with low friction composite materials, the lifeboat is released from the top of the slipway and proceeds under its own weight into the water. The lifeboat is subsequently recovered to the top of the slipway using a winch line. With the introduction of the new, larger 'Tamar' class lifeboat it is necessary to upgrade existing boathouses and standardise slipway operational procedures to ensure consistent operation. The higher contact pressures and launch velocities associated with the new lifeboat have led to issues of high friction and wear on the low friction composite linings and a number of methods have been adopted to mitigate this effect. This paper presents a methodology for assessing slipway lining performance so that friction and wear conditions along the slipway can be monitored to ensure consistent operation. A multidisciplinary approach using tribometer testing in conjunction with finite element analysis and real world slipway condition surveys is adopted to extend the scope of investigation to incorporate common real world effects such as panel misalignments. Various lubricants are assessed for their suitability with regard to friction and wear performance in addition to sustainability considerations using the methodology, and modifications to the design of slipway panels, guidelines for lifeboat operation procedures and suitable panel installation tolerances are developed. Finally, new slipway condition monitoring procedures are proposed
\end{abstract}


incorporating slipway panel failure and replacement criteria and recovery winch based condition monitoring.

Keywords: lifeboats, tribology, wear, friction, slipway.

\section{Introduction}

The RNLI provides marine search and rescue cover to the UK and Ireland; this is achieved using a range of lifeboats and lifeboat stations positioned around the UK according to local conditions. If possible a natural harbour is used to store the lifeboat when not in use, however, at certain points around the UK there is no suitable natural harbour located to allow continuous coastal cover within the range of current lifeboats; here a slipway station is used. Lifeboat slipway stations use an inclined slipway with the lifeboat kept in a large boathouse at the top of the slipway, to launch, the lifeboat is released from the boathouse and proceeds under its own weight down the slipway into the water.

The RNLI operates 18 slipway stations in the UK and 2 in the Republic of Ireland, each station is different and each has its own historical launch techniques and slipway geometries though they all follow a common template [1]. The most common configuration is to have an upper section of steel rollers leading onto a smooth, lined, lower section. The boat is launched down the slipway with the plane slipway section coated with grease and recovered by manoeuvring the lifeboat onto the bottom of the slipway before attaching a winch cable and hauling the boat to the top of the slipway. Slipway inclines rage from 1 in 5 to 1 in 6 with most using a gradient of 1 in 5.The lower section of the slipway has been lined with a number of different materials through the years and currently utilises a graphite infused jute/phenolic resin composite selected for its low friction coefficient.

A variation on this slipway design uses steel rollers along the whole length of the slipway and a shallower slipway incline for areas with shallow beaches. This configuration works well for launches but can be very difficult to operate during the lifeboat recovery phase due to the difficulty in locating the lifeboat on the steel rollers prior to recovery. One innovative solution to this problem is to use

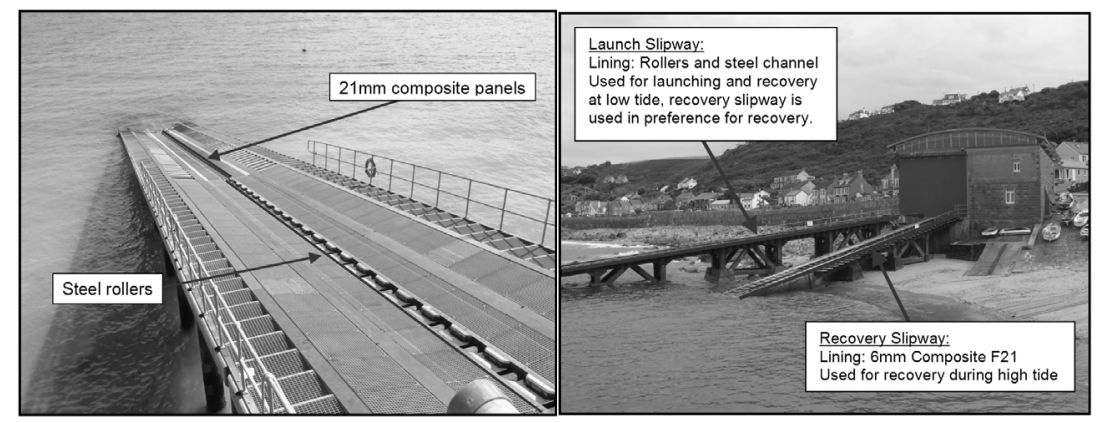

Figure 1: Slipway station variations - left, typical configuration at Padstow, right, separate launch and recovery slipways at Sennen Cove. 
separate slipways for launch and recovery as at Sennen Cove (fig. 1) with a rotating cradle to transfer the lifeboat back onto the launch slipway once in the boathouse.

Improvements in lifeboat safety, instrumentation, speed and range have led to a steady increase in lifeboat size and mass and this has meant significant upgrading to slipways and boathouses through the years [2]. The Tamar is the latest slipway lifeboat design to be adopted, being introduced from 2006 and is the largest, heaviest slipway lifeboat yet used [3].

This has presented serious problems for slipway station operation with slipway contact pressures and winch loads increasing significantly. This has manifested as problems during lifeboat recovery with increasing winch loads, high friction and high wear along the plane, lined slipway section. Historically problems of high friction during launch or recovery have been addressed by manually applying marine grease to the slipway, and this has become common practice when operating the predecessor to the Tamar, the Tyne. The widespread manual application of marine grease on lifeboat slipways has implications for crew safety, cost and for the local environment and alternative solutions to high friction issues are to be sought. Similarly, higher contact pressures at the contact of the Tamar keel on the slipway lining in comparison to it predecessor have led to severe wear observed on the composite slipway lining panels. This has meant that composite panels designed to last for around two years are requiring replacement in a matter of months or even weeks. The composite panels are expensive, and at current replacement rates the panels are estimated to cost the RNLI around $£ 260,000$ per year [4] once the Tamar has been fully deployed to all slipway stations.

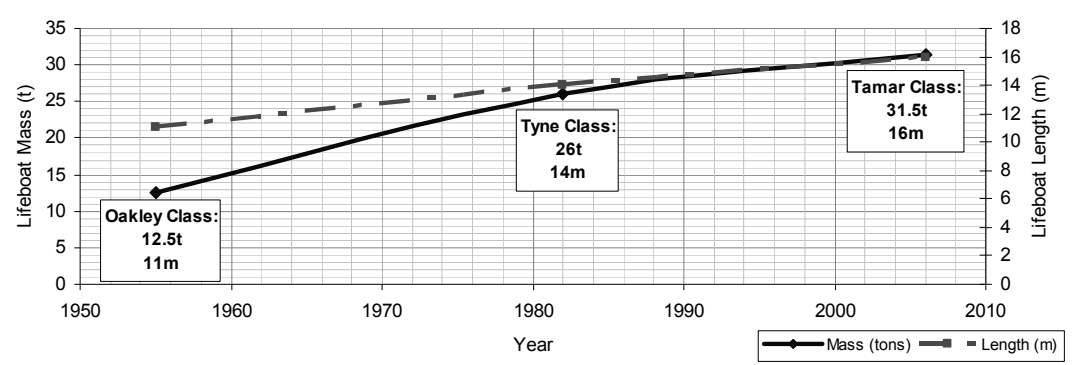

Figure 2: $\quad$ Slipway lifeboats mass and length over time.

\section{Methodology}

\subsection{Initial investigations}

The lifeboat slipway problem is investigated using a multidisciplinary approach. Initial investigations focus on site surveys and detailed investigation of worn slipway panels with additional friction data provided by RNLI line pull trials [5]. These showed characteristic wear patterns on the slipway panels and also indicated that there was significant misalignment of up to $4 \mathrm{~mm}$ in height 
between panels. Initial concerns were raised as to the effects of these panel misalignments on the lifeboat keel contact.

Slipway line pull trials involve placing a load cell in line with the recovery winch to measure the friction along the slipway as the boat is hauled into the boathouse. These are regularly conducted by the RNLI at all slipway station to monitor slipway and winch performance. The data from these trials was investigated for any indications regarding the performance of the slipway lining panels.

\subsubsection{Slipway geometry analysis}

In addition to the site surveys and line pull data collected it was necessary to investigate the slipway geometry to derive an appropriate friction specification. It is found that for the most common configuration using a slipway incline of 1 in 5 the maximum friction coefficient is 0.2 . For the shallower 1 in 6 configuration this falls to 0.167 . However, the winch specification in all cases is for a 12 tonne maximum winch load, in the 1 in 5 gradient slipway case this reduces the maximum friction coefficient specification to 0.15 . For the 1 in 6 gradient slipways the maximum friction coefficient required by the winch is $\mu=0.181$. This prompts the immediate recommendation that the recovery winch be specified according to the slipway incline, increasing the winch specification for the 1 in 5 incline from 12 tonnes to 13.7 tonnes allows the maximum friction specification for the slipway lining material to rise from 0.15 to 0.2 . Conversely, the winch specifications for the 1 in 6 gradient slipway stations can be relaxed to 11.5 tonnes to match the geometric friction coefficient of $\mu=0.167$.

The current composite slipway lining has a listed dry sliding friction coefficient of $\mu=0.25$ which implies that it must be used with a lubricant in all cases.

\subsection{Initial experimental testing}

To gain a more complete picture of the contact mechanisms at work in this case samples of the slipway lining and the steel keel are tested using rotary and reciprocating tribometers. The friction and wear performance of the contact pair under various contact pressures and lubrication regimes is tested with initial screening friction and wear tests conducted on a modified Plint TE57 [6] under a pin on plate configuration with a lubricant bath to contain the lubricant. The Plint TE92 rotary tribometer [7] is used in a modified ring on ring arrangement to perform extended wear tests under varying contact pressure and lubricants.

Tests were conducted at contact pressures from $60-740 \mathrm{kPa}$ with the real world contact pressure calculated as $148 \mathrm{kPa}$, the upper contact pressure limit tested represents five times this value. Tests were conducted under dry sliding conditions, using the marine grease currently used on most slipways, using freshwater and seawater lubrication, and using alternate lubricants - two biodegradable greases and a microsphere emulsion, originally intended as a cable pulling lubricant and used on the Sennen Cove recovery slipway.

The results from the testing indicate a number of points, the first being that the wear generated by the full lifespan rotary tests, designed to replicate the 
sliding experienced during the two year design life of the composite panels, was very low under all lubrication conditions and insufficient to explain the high panel failure rates experienced at Tenby and Padstow. This indicates that real world wear is likely to occur under different conditions than those tested here.

The second point raised by the testing confirms that the friction performance under dry sliding conditions is insufficient to meet the criteria identified above. This prompts the recommendation to discontinue any unlubricated running of lifeboat slipways. All lubricants tested performed sufficiently well to allow safe running of the lifeboat, although one of the biogreases tested and both water lubricated cases are close to the friction coefficient limit.

The presence of graphite in the composite indicates that a transfer layer is likely to form under dry sliding conditions, and this is seem in the smooth, reflective surface shown in fig. 3, this is also shown when the surface is inspected using profile inferometry with the roughness of the dry sliding wear scar markedly less than the virgin material. The presence of lubricants in the
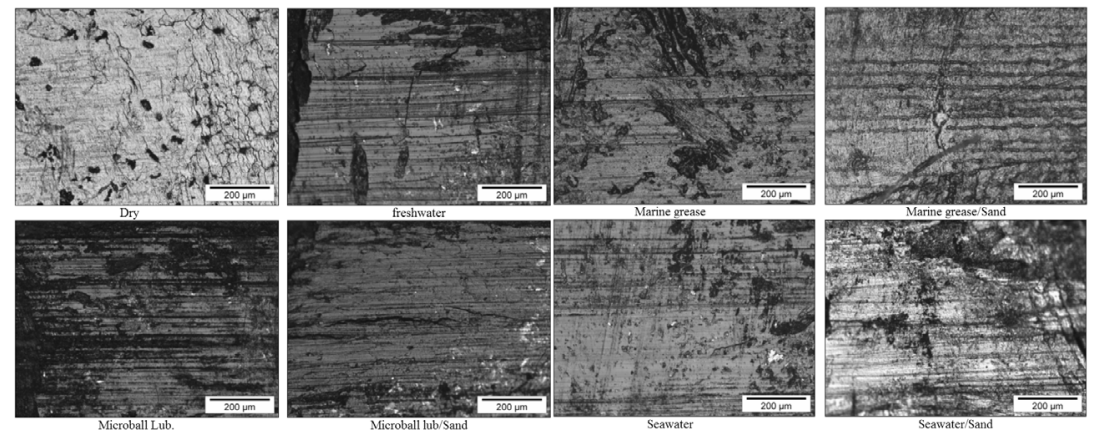

Figure 3: TE57 reciprocating tribometer: wear scar images, L-R dry, freshwater, marine grease, marine grease/sand, microball lubricant, microball lubricant/sand, seawater, seawater/sand.

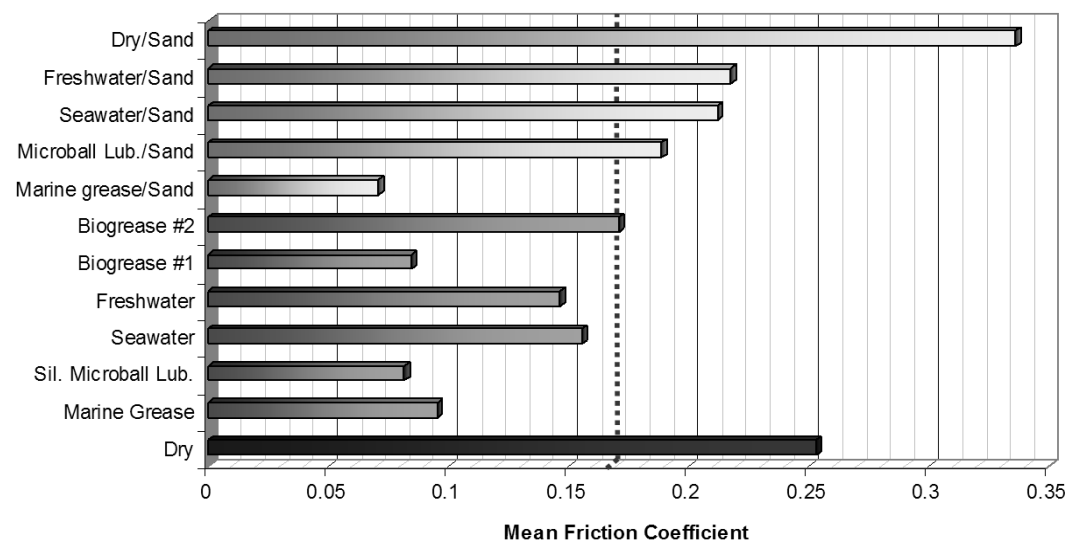

Figure 4: TE57 reciprocating tribometer: friction results. 

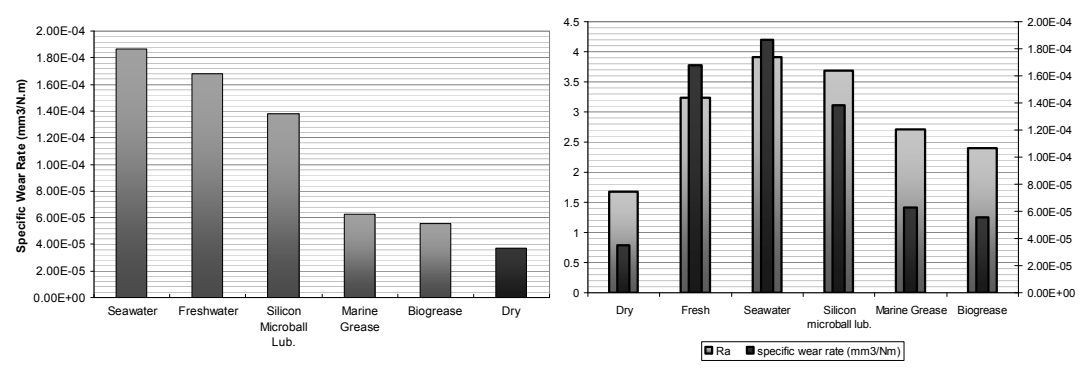

Figure 5: $\quad$ TE92 rotary tribometer: wear and surface roughness results.

contact region is known to interfere with the formation of a graphite contact layer [8] and this is seen in the partially smooth surfaces shown under lubricated conditions.

We would expect the wear rate of a sliding contact to be reduced by the presence of lubricants, however in this case the dry sliding wear rate is mitigated by the presence of a transfer layer and is particularly low, while the presence of lubricants acts to disrupt this transfer layer leading to the increase in wear rates in the presence of lubricants. To check this, the surface roughness of the wear scar is recorded and compared to the dry sliding case as an indication to the extent of the graphite transfer layer development. In all cases the surface roughness is higher in the presence of a lubricant which indicates that the smoothing effect of a graphite transfer layer is less developed, the surface roughness and wear rates show a good correlation indicating that the transfer layer performs an important role in reducing dry sliding wear. It should be noted however that the wear rate recorded in all cases is low, and not sufficient to explain the high panel failure rates encountered on real world slipways.

\subsection{Further analysis}

Following the tribometer wear results which indicated that the wear rates under aligned conditions are insufficient to explain the failure rates seen in real life, the scope of the research was developed using Finite Element analysis in ANSYS [5]. This was used initially to model the aligned case, where wear scar development was seen to correspond well with the real world case, and also to investigate the likely effects of the panel misalignments seen in the slipway surveys. These misalignments can be split into three main types, parallel offset, where one panel is raised in reference to its predecessor while remaining parallel, angled offset, where one end of the panel is raised in relation to its neighbour and the raised panel is pitched at an angle along its length, and skewed misalignment, where one panel is angled longitudinally in regard to its predecessor, corkscrew fashion. These scenarios are each tested for panel offsets of $0-5 \mathrm{~mm}$ as indicated by the slipway surveys conducted.

The results show that the effects of panel misalignment are significant, as the contact moves away from the evenly distributed case the contact stresses and consequently wear, increase dramatically. The increase in contact stresses at the 


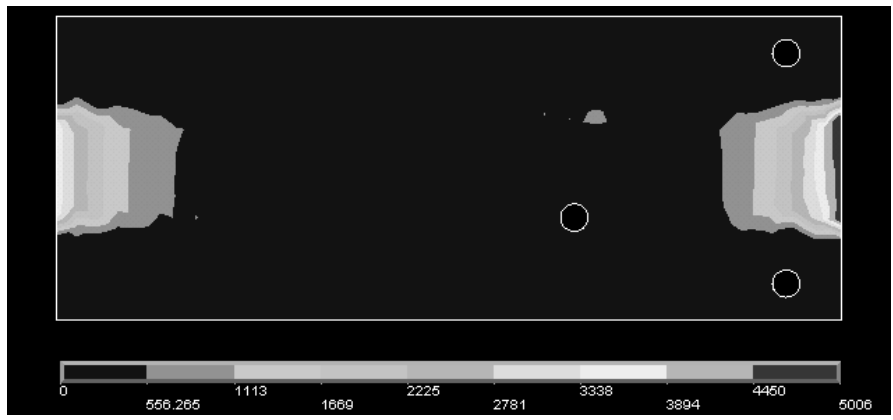

Figure 6: FEA: Friction map for misaligned panel (raised edge on the right).

raised regions is also a major factor in the friction performance of the panel, with panel friction maps also showing increases in frictional forces at the raised panel regions.

Table 1: $\quad$ Panel misalignment apparent friction coefficient contribution.

\begin{tabular}{|c|c|c|c|}
\hline Offset & Parallel & Angled & Skewed \\
\hline 0 & 0.028 & 0.028 & 0.028 \\
\hline 1 & 0.503 & 0.247 & 0.164 \\
\hline 2 & 1.035 & 0.492 & 0.368 \\
\hline 3 & 1.565 & 0.742 & 0.582 \\
\hline 4 & 1.752 & 0.984 & 0.827 \\
\hline 5 & 2.194 & 1.215 & 1.042 \\
\hline
\end{tabular}

The end result of this is that the slipway recovery winch encounters higher friction forces than would be expected for an ideally aligned plane case, this can be interpreted as an increase in the apparent friction coefficient (although in reality the friction coefficient remains the same and the increase in frictional forces is a consequence of misrepresenting the contact case).

Wear is noted during real world surveys to occur most severely on misaligned slipway panels and this is reflected in the FEA models, with good correlation between real and simulated wear scars found.
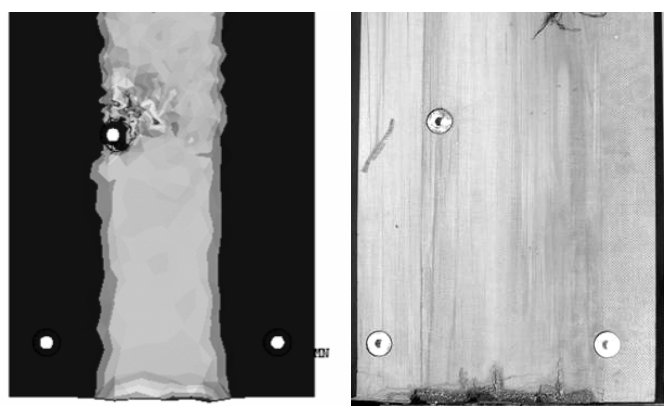

Figure 7: $\quad$ FEA: Simulated vs. real world wear on a misaligned panel. 
These results indicate that it is likely that panel misalignments play an important role in both the friction and wear of real world slipway panels and this allows development and testing of a panel design that will reduce the effects of panel misalignments.

\subsubsection{Solution proposed}

The panel misalignments found during the slipway condition surveys were up to a $5 \mathrm{~mm}$ step, however, it is seen from this analysis that even small panel misalignments can still have a serious effect on friction and wear; in fact the largest offset height that can be accommodated within the plastic deformation of the composite panel is just $0.361 \mathrm{~mm}$. Because of this, and because of the practical difficulties in reducing real world panel misalignments below this level it is decided to focus on techniques to limit the effect of panel misalignments, rather than attempt to eliminate the misalignments themselves. A panel modification to feature a chamfer at each end is proposed to reduce the stress concentration effects at the raised edges of panel misalignments and their consequent effects on panel friction and wear performance.

The aim of this panel is to allow reliable friction and wear performance along the slipway within current panel alignment standards.
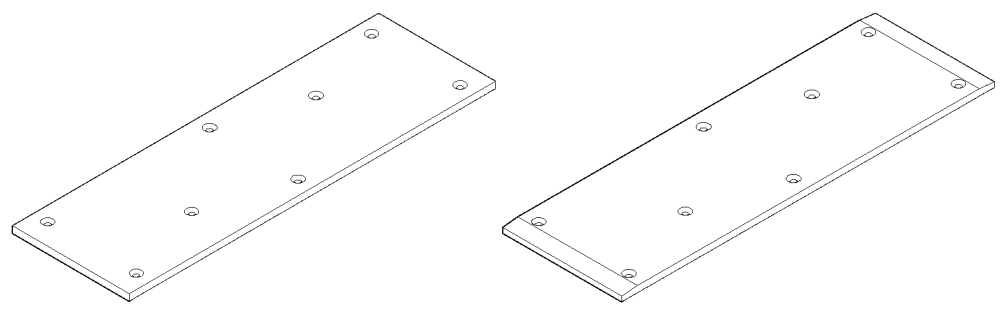

Figure 8: $\quad$ Original (left) and modified (right) slipway panels.

\begin{tabular}{|l|l|l|l|l|l|l|l|l|}
\hline Lubricant & \multicolumn{7}{|c|}{ Wear Rate (mm/m slide) } \\
\hline Seawater & $6.11 \mathrm{E}-03$ & $5.09 \mathrm{E}-03$ & $4.08 \mathrm{E}-03$ & $3.06 \mathrm{E}-03$ & $2.04 \mathrm{E}-03$ & $1.02 \mathrm{E}-03$ & $5.09 \mathrm{E}-04$ & $1.02 \mathrm{E}-04$ \\
\hline Freshwater & $5.50 \mathrm{E}-03$ & $4.59 \mathrm{E}-03$ & $3.67 \mathrm{E}-03$ & $2.75 \mathrm{E}-03$ & $1.83 \mathrm{E}-03$ & $9.17 \mathrm{E}-04$ & $4.59 \mathrm{E}-04$ & $9.17 \mathrm{E}-05$ \\
\hline Microball Lub. & $4.53 \mathrm{E}-03$ & $3.78 \mathrm{E}-03$ & $3.02 \mathrm{E}-03$ & $2.27 \mathrm{E}-03$ & $1.51 \mathrm{E}-03$ & $7.56 \mathrm{E}-04$ & $3.78 \mathrm{E}-04$ & $7.56 \mathrm{E}-05$ \\
\hline Marine Grease & $2.06 \mathrm{E}-03$ & $1.72 \mathrm{E}-03$ & $1.37 \mathrm{E}-03$ & $1.03 \mathrm{E}-03$ & $6.86 \mathrm{E}-04$ & $3.43 \mathrm{E}-04$ & $1.72 \mathrm{E}-04$ & $3.43 \mathrm{E}-05$ \\
\hline Biogrease \#1 & $1.82 \mathrm{E}-03$ & $1.52 \mathrm{E}-03$ & $1.22 \mathrm{E}-03$ & $9.12 \mathrm{E}-04$ & $6.08 \mathrm{E}-04$ & $3.04 \mathrm{E}-04$ & $1.52 \mathrm{E}-04$ & $3.04 \mathrm{E}-05$ \\
\hline Dry & $1.21 \mathrm{E}-03$ & $1.01 \mathrm{E}-03$ & $8.09 \mathrm{E}-04$ & $6.07 \mathrm{E}-04$ & $4.05 \mathrm{E}-04$ & $2.02 \mathrm{E}-04$ & $1.01 \mathrm{E}-04$ & $2.02 \mathrm{E}-05$ \\
\hline
\end{tabular}

Figure 9: Wear map comparison - chamfer panel (top), Original panel (bottom). 


\subsubsection{Solution tested}

The chamfered panel is tested using the FEA model developed for the original panel alignment modelling and is found to significantly improve the panel's performance. Chamfer optimisation tests indicate that a chamfer geometry of 5 by $60 \mathrm{~mm}$ will have the most significant effect with stress reductions of around $70 \%$ and wear and friction reductions of around $60 \%$ compared with the original panel for all offsets up to $5 \mathrm{~mm}$ in height.

\section{Discussion}

The multidisciplinary methodology adopted in this case is shown to be necessary to provide a sufficiently broad understanding of the slipway contact case. It is shown that the tribometer testing alone does not give a full enough understanding of the real world issues affecting slipway friction and wear, and that with the large scale test rigs required to investigate panel misalignment effects experimentally proving impractical, it is appropriate to continue the research using finite element simulations of the contact informed by the previous tribometer testing results.

The initial tribometer testing give valuable insight into the role of lubricants in the lifeboat slipway case, it is found that the composite selected is unsuitable for dry running due to its high friction coefficient and must therefore be used with lubricants. It is also shown that the presence of lubricants in the contact disrupts the formation of a protective graphite transfer layer to mitigate wear and friction effects, this indicates that the inclusion of graphite in the currently selected composite is unnecessary, and that other similar composite materials without included graphite may prove more suitable.

With the use of lubricants shown to be necessary the tribometer tests indicate that all lubricants tested could potentially reduce the friction to operable levels, with water lubrication particularly interesting due to its low cost and environmental impact.

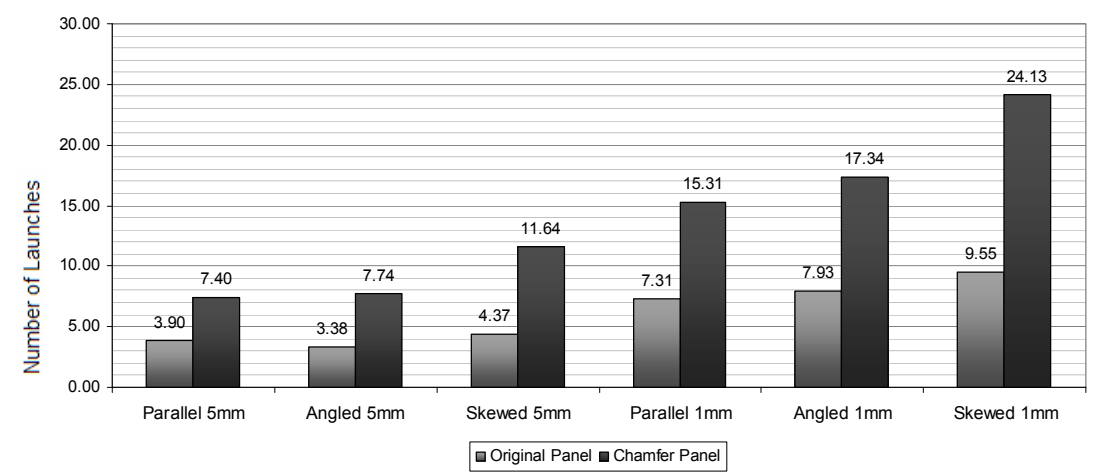

Figure 10: Launches/recoveries required for the slipway panel to fail for original and modified slipway panels using freshwater lubrication. 


\subsection{Panel lifespan}

The Finite Element results indicate that the panel misalignments observed during real world slipway surveys are an important contributor to the apparent friction along the slipway, but it is shown that these effects can be significantly reduced by incorporating a chamfer into the panel design. The use of chamfered panel to reduce misalignment effects should allow lifeboat slipways to operate reliably using water lubrication, and is also predicted to significantly improve the expected lifespan of the composite panels.

\subsection{Cost}

The use of water lubrication in conjunction with the chamfered panels is shown using life cycle analysis to offer significant financial savings compared with the current manually applied grease lubrication as well as better environmental and safety performance. It is thought that the adoption of either sea or freshwater lubrication systems and chamfer panels will save almost $£ 200 \mathrm{k} / \mathrm{p}$.a. compared to

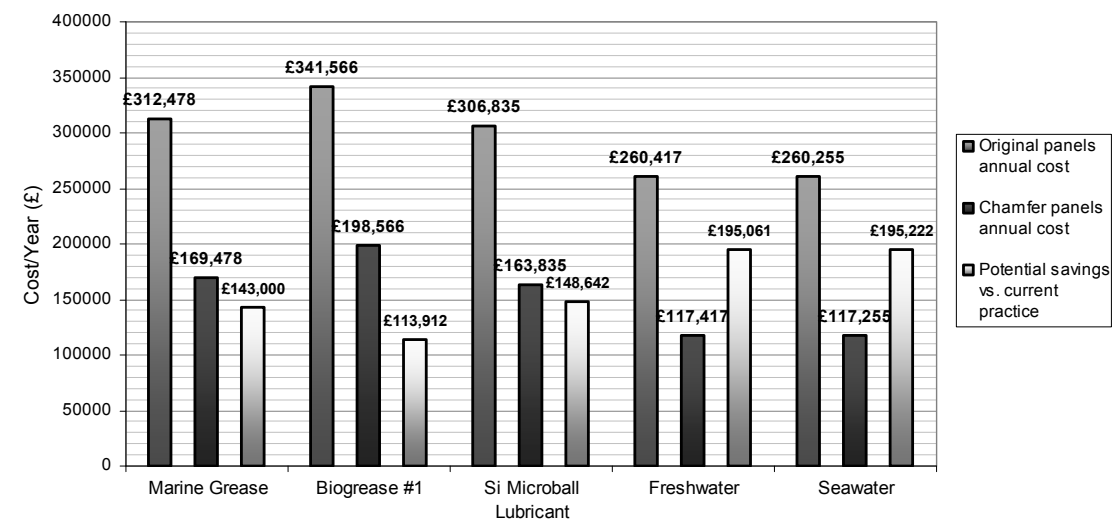

Figure 11: $\quad$ Slipway operating costs/year - original panel vs. chamfer panel.

current practice, a saving of $62 \%$. This is the combined result of reduced panel replacement costs due to the reduction in panel misalignment edge effects using the chamfered panels, and the reduced cost of the lubricant itself.

Table 2: $\quad$ Panel misalignment effects on friction coefficients.

\begin{tabular}{|c|c|c|c|c|c|c|}
\hline $\begin{array}{c}\text { Offset dist. } \\
(\mathbf{m m})\end{array}$ & \multicolumn{2}{|c|}{ Parallel Misalignment } & \multicolumn{2}{c|}{ Angled Misalignment } & \multicolumn{2}{c|}{ Skewed Misalignment } \\
\cline { 2 - 7 } & Original & Chamfer & Original & Chamfer & Original & Chamfer \\
\hline 0 & 0.028 & 0.054 & 0.028 & 0.054 & 0.028 & 0.054 \\
\hline 1 & 0.503 & 0.109 & 0.247 & 0.227 & 0.164 & 0.107 \\
\hline 2 & 1.035 & 0.210 & 0.492 & 0.464 & 0.368 & 0.265 \\
\hline 3 & 1.565 & 0.313 & 0.742 & 0.520 & 0.582 & 0.385 \\
\hline 4 & 1.752 & 0.417 & 0.984 & 0.662 & 0.827 & 0.606 \\
\hline 5 & 2.194 & 0.519 & 1.215 & 1.123 & 1.042 & 0.806 \\
\hline
\end{tabular}




\subsection{Friction performance}

The FEA simulations show that the use of a chamfer on the slipway panels can greatly reduce the friction contributions of panel misalignments and this is shown in table 2 for a typical $1 \mathrm{~mm}$ offset.

\section{Conclusions}

The research conclusions can be summarised as follows:

- It is shown that consistent, low friction using composite slipway panels is only reliably achievable using lubricants.

- The use of biogrease \#1 is shown to be as effective as current marine grease practice and this can be considered a candidate for direct substitution with due consideration given to the increased cost of biogrease \#1.

- The use of water lubrication is shown to be effective under good slipway alignment conditions and is also shown to offer significant environmental and economic benefits.

- Current slipway winch specifications are shown to be the limiting factor when calculating friction specifications on 1 in 5 slipways and these should be increased as described above.

- The effects of contaminated contact conditions (i.e. windblown sand) are shown to be severe, however real world instances of this were rare and this can be discounted as a systemic factor in slipway panel wear.

- Slipway panel geometry and alignment is shown to be an important factor in determining the real world friction and wear performance of composite slipway panels.

- The use of a modified chamfer panel in place of the current panel design is shown to reduce the effects of panel misalignments leading to reduced wear and friction on slipway panels.

- Slipway panels are shown to fail due to friction specifications rather that panel material failure so that slipway wear performance can be assessed at each slipway station using winch loads criteria.

- Slipway panel failure criteria can be developed by assessing the bearing area of the panel surface.

- Reducing panel misalignment and using chamfered slipway panels is shown to more than double current panel life spans.

- Using water lubrication and chamfered slipway panels could potentially save up to $£ 195 \mathrm{k}$ per year whilst improving the safety, reliability and panel lifespan of slipway launched lifeboat operation.

\section{Recommendations}

Recommendations for slipway lifeboat operation derived from this research are shown below: 
- Winch specifications for various slipway angles should be assessed using calculations outlined above. This shows that increasing the winch line pull specification from 12 tonnes to 13.7 tonnes for 1 in 5 gradient slipways will allow for a far greater friction coefficient tolerance. By the same analysis, for shallower 1 in 6 slipways the winch specification can be relaxed to 11.5 tonnes.

- It is recommended to adopt water lubrication systems across the RNLI slipway station network as this is shown to be effective and reliable while also reducing operating costs.

- It is recommended that the use of greases along the slipway be relegated to a backup system for water lubrication due to the economic, environmental and safety implications inherent in direct grease application to the slipway.

- The direct substitution of marine grease with biogrease \#1 is shown to be feasible and this should be considered with appropriate assessment of the relative importance of economic and environmental factors.

- Panel misalignments are shown to be a significant factor in real world slipway friction and a maximum panel alignment specification of $2 \mathrm{~mm}$ is recommended to prevent high friction and wear occurrences. This target should be feasible within current slipway panel fitting practices.

- Slipway condition monitoring using winch loading is shown to be effective at assessing slipway performance and it is recommended that this practice be adopted across all slipway stations.

- Individual slipway panel conditions can be assessed using the bearing area failure criteria developed, and this is recommended for adoption in conjunction with winch load monitoring.

- Further testing of alternative materials is proposed as the inclusion of graphite in the current composite material is shown to be unnecessary and more suitable materials may be available.

\section{References}

[1] Warner, O: 'The lifeboat service: a history of the Royal National Lifeboat Institution, 1824-1974' London : Cassell, (1974)

[2] Leach, N: 'A Century of RNLI Motor Lifeboats' Landmark Publishing Ltd. (2007)

[3] Hudson, F, D: 'The design and development of modern SAR craft - A personal view' The Royal Institution of Naval Architects, Drydocks, Launching, and Shiplift Conference, pp79-82. (2003)

[4] Austen, S: RNLI Head of Engineering Support - Private communication, $5^{\text {th }}$ June (2008)

[5] Thomas, B, Hadfield, M, Austen, S: 'Wear and Friction Modelling on Lifeboat Launch Systems' Tribology Transaction, in press (2009)

[6] Thomas, B, Hadfield, M, Austen, S: 'Experimental Wear Modelling of Lifeboat Slipway Launches' Tribology International, Vol. 42, Issues 11-12, p1706-14 (2009) 
[7] Thomas, B, Hadfield, M, Austen, S: 'Wear Observations Applied to Lifeboat Slipway Launches' WEAR, Vol. 267, Issue 11, p2062-9 (2009)

[8] Sinha, Sujeet, K: 'Wear Failures of Plastics' p1019-27, in 'ASM Handbook: Failure Analysis and Prevention Vol. 11: Failure Analysis and Prevention', ASM International (2002) 